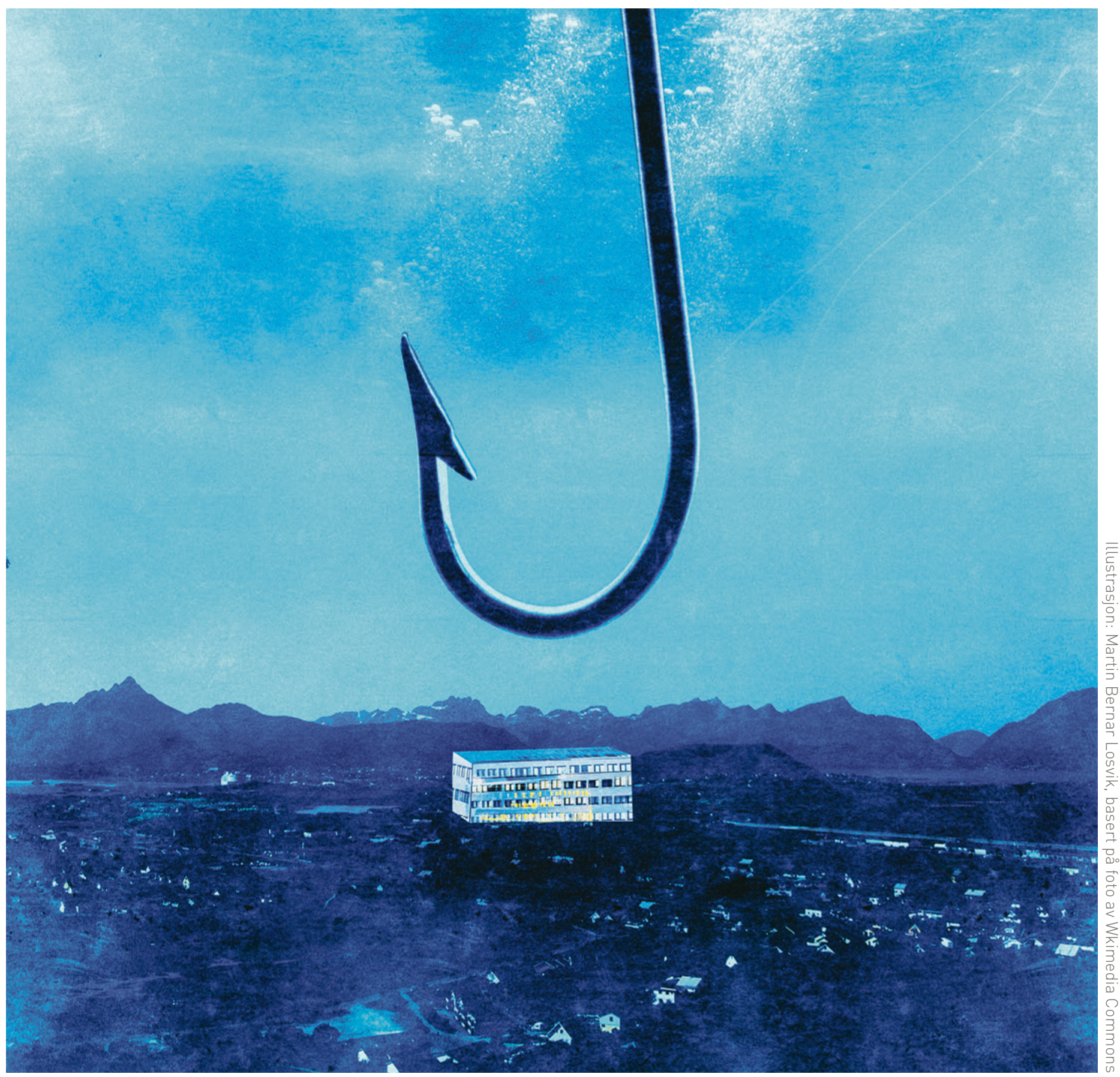

\title{
Leknes legesenter
}

(

Ved Leknes legesenter arbeider seks leger og fem helsesekretærer. Leknes fikk bystatus i 2002

og er administrasjonssenteret i Vestvågøy kommune i Nordland. Tettstedet har drøyt 3000 innbyggere. 